\title{
Prevalence and factors associated with constipation in premenopausal women: a community-based study
}

\author{
Amanda Almeida Gomes DANTAS ${ }^{1}$, Isabelle Ribeiro BARBOSA ${ }^{1}$, Shamyr Sulyvan de CASTRO², \\ Caroline Wanderley Souto FERREIRA ${ }^{3}$, Saionara Maria Aires da CAMARA ${ }^{1}$ and Diego de Sousa DANTAS ${ }^{1,3}$
}

Received: 28 January 2020 Accepted: 26 March 2020

\begin{abstract}
Background - Intestinal constipation is characterized by problems related to evacuation, and presents high prevalence in the female gender. This condition has demonstrated negative effects on the development of daily activities, causing damage to the physical and emotional well-being of individuals who are diagnosed with it. Studies that investigate what health impairments intestinal constipation can cause are scarce in the literature. Objective - This study aimed to verify the prevalence and factors associated with intestinal constipation in premenopausal women living in Northeastern Brazil. Methods - It is a cross-sectional study. This was carried out in the northeast of Brazil. Participated 195 women, adult and middle age. Social conditions, habits and lifestyle, clinical aspects and obstetric history were investigated. Constipation was diagnosed using the Rome III Criteria. Multivariate analysis was conducted using Poisson Regression with robust variance to analyze the relationship between intestinal constipation and independent variables. A statistical significance level of $P<0.05$ was considered. Results - Most of the women were between 25 and 39 years old $(49.2 \%)$ and had an income of up to one minimum wage (79.5\%). The intestinal constipation prevalence was $35.4 \%$. In the final multivariate regression model, hemorrhoid clinical aspects $(P=0.01)$, pain $(P=0.001)$ and a burning sensation $(P=0.01)$ on bowel movement, and sexual dysfunction $(P=0.03)$ remained associated with constipation. Conclusion - The present study found a significant prevalence of constipation among premenopausal women and clinical factors such as hemorrhoids, pain and a burning sensation, and sexual dysfunction were associated with intestinal constipation.
\end{abstract}

HEADINGS - Constipation. Women's health. Premenopause. Epidemiology.

\section{INTRODUCTION}

According to the World Gastroenterology Organization ${ }^{(1)}$, intestinal constipation (IC) is characterized by a constant complication to perform bowel movements, incomplete bowel movements, as well as infrequent bowel movements, which are present every 3 or 4 days, or less frequently, and in the absence of alarming symptoms or secondary factors.

Constipation is a common, expensive and costly condition for health services ${ }^{(2)}$, with an estimated worldwide prevalence ranging from $1 \%$ to $80 \%$ due to the geographical and methodological divergences of the studies. Overall, the average prevalence of constipation in adults has been estimated at $16 \%$ worldwide, while reaching $34 \%$ among older adults ${ }^{(3,4)}$, and with females being more prone to this condition ${ }^{(5,6)}$.

Women have estrogen and progesterone-related biological issues that directly interfere with gastrointestinal motility through activation of the autonomic nervous system, which may lead to developing constipation ${ }^{(7)}$.

Through a systematic review, Belsey ${ }^{(8)}$ reported that constipation compromises people's quality of life in physical and mental health aspects, and that the impact of IC on adults is similar to that noted in conditions which can be estimated to be more "severe" such as osteoarthritis, rheumatoid arthritis, chronic allergies, and diabetes.

In this context, the importance of investigating the prevalence and factors associated with IC in women is emphasized so that recent epidemiological data can assist researchers and professionals in health promotion and preventing this condition, as there is a gap in scientific knowledge about this outcome. Thus, this study aims to analyze the prevalence and factors associated with intestinal constipation in premenopausal women living in a municipality in northeast Brazil.

\section{METHODS}

This is a cross-sectional study conducted in the urban territory of Santa Cruz-RN from December 2015 to November 2016. The research protocol was submitted and approved by the local Research Ethics Committee at Federal University of Rio Grande do Norte under the CAAE number: 49237315.9.0000.5568. The study was conducted in line with the terms of the Declaration of Helsinki.

Declared conflict of interest of all authors: none

Disclosure of funding: no funding received

${ }^{1}$ Universidade Federal do Rio Grande do Norte, Faculdade de Ciências da Saúde de Trairi (FACISA), Santa Cruz, RN, Brasil. ${ }^{2}$ Universidade Federal do Ceará, Fortaleza, CE, Brasil.

${ }^{3}$ Universidade Federal de Pernambuco, Recife, PE, Brasil.

Corresponding author: Diego de Sousa Dantas. E-mail: diegodantas1@gmail.com 
Santa Cruz is a small city with low economic potential located in the interior of Northeastern Brazil, in the rugged interior Potiguar $(\mathrm{RN})$ region with 38,538 inhabitants and an area of $624.356 \mathrm{~km}$. The municipality has health coverage of $97.83 \%$ by the Family Health Program (PSF). In this sample, 11,736 inhabitants are women of reproductive age aged between 10 and 49 years, representing $30.45 \%$ of the total resident population in this location ${ }^{(9)}$.

The sample size calculation considered a prevalence of $36.9 \%$ of constipation in women ${ }^{(10)}$, a relative error of $20 \%$ and a nonresponse rate of $15 \%$, resulting in a sample of 194 participants.

The sample composition was performed by proportional stratified sampling based on the health territories assigned to the family health units of the municipality and women were recruited through an active search.

The study included women of reproductive age (19 and 49 years old), non-pregnant women with regular menstrual cycle and who agreed to participate by signing the informed consent form. Women with cognitive impairment which prevented applying questionnaires or who did not finalize the research protocol would have been excluded, however no participants were excluded in the present study. Pregnant women were not included as it is known that the risk of constipation is high during pregnancy due to the significant increase in sex hormones, reduced bowel movement and emptying due to mechanical compression caused by the placenta ${ }^{(4)}$.

Data collection was performed by previously trained interviewers in their own health units. The participants were invited to this study while waiting for habitual appointment. The participants answered questions about hers life and the Rome III Criterion ${ }^{(11)}$, considered the gold standard, to define the dependent study variable, which was IC. The same instrument was used as data collection began in December 2015, as the Rome IV criterion had not yet been published. This instrument was applied in a room available in each health unit, seeking to preserve or confidentiality of the data collected. It is worth noting that no woman refused or gave up to collaborate with this research.

The Rome III criterion is a collective product of committees and medical societies developed by experts in the field, and refers to a uniform instrument for making the most accurate IC diagnosis. According to this criterion, the symptoms for diagnosing constipation must start six months before the evaluation, and must be active for at least three months in at least one quarter of the bowel movements, and the individual must have two or more symptoms from the questionnaire's own list, including: a) less than three bowel movements per week, b) straining when evacuating, c) the presence of hard or broken stools, d) feeling of incomplete bowel movement, e) feeling of anorectal block, and f) manual maneuvers to facilitate evacuations ${ }^{(11)}$.

The analyzed independent variables involved questions related to: a) population characterization: age group, which was grouped according to life cycle, namely: young adult (19 to 24 years old), adult ( 25 to 39 years old) and middle aged ( 40 to 49 years); marital status, which was dichotomized into with and without a partner; ethnicity, grouped in white and others; education, which was considered until elementary school and high school or higher; and income, which was grouped up to 1 minimum monthly salary and $>1$ minimum monthly salary; b) lifestyle: physical inactivity and self-rated of health dichotomized into poor (bad or very bad) and good (regular, good and very good) health; c) clinical aspects, measured by self-report: hemorrhoids, pain during evacuation, pruritus ani, presence of blood in the stool and burning sensa- tion during the bowel movement; and d) reproductive history, which included types of delivery, episiotomy, dysmenorrhea and sexual dysfunction.

Physical inactivity was assessed through the short version of the IPAQ - International Physical Activity Questionnaire ${ }^{(12)}$, validated for the Brazilian population. IPAQ quantifies energy expenditure in METs-minute/week with physical activity. Women with lower values $<600$ METs-minute/week are considered sedentary ${ }^{(13)}$.

Self-rated health was assessed using the five-point likert scale for the question "How do you rate your health at this time?", being categorized as: fair, good, very good, bad and very bad ${ }^{(14)}$.

Sexual dysfunction was assessed by the Female Sexual Quotient $(\mathrm{FSQ})^{(15)}$. This questionnaire assesses various domains of women's sexual activity. Women with a score of 60 points or less were considered as having sexual dysfunction, according to the cut-off point established for screening for dysfunction ${ }^{(16)}$

Data were tabulated and analyzed using the Statistical Package for Social Sciences (SPSS) version 22.0 software. Descriptive and inferential statistics were employed for data analysis. Bivariate analysis was performed using the chi-squared test. Poisson regression with robust variance was used to estimate gross and adjusted prevalence ratios (PR) of intestinal constipation and to calculate the respective confidence interval $(95 \% \mathrm{CI})$. Variables with significant association $(P \leq 0.20)$ were included in the multivariate model in the bivariate analysis for the crude PR analysis, and only those variables that had statistical significance of $(P \leq 0.05)$ were included in the adjusted model. The Multivariate analysis was conducted using Poisson regression with robust variance.

\section{RESULTS}

There were 195 women included in the study and the prevalence of constipation was $35.4 \%$.

In the bivariate analysis, the clinical variables hemorrhoids ( $P=0.03)$, pain during evacuation $(P=0.001)$, pruritus ani $(P=0.03)$, presence of blood in the stool $(P=0.001)$, burning sensation during evacuation $(P=0.001)$, dysmenorrhea $(P=0.05)$ and sexual dysfunction $(P=0.02)$ were associated with constipation. The sociodemographic and lifestyle variables did not present a statistically significant difference between the groups (TABLE 1).

Through multivariate analysis it was observed that the variables pain $(P=0.001)$ and burning during evacuation $(P=0.01)$, hemorrhoids $(P=0.01)$ and sexual dysfunction $(P=0.03)$ remained associated to CI (TABLE 2).

\section{DISCUSSION}

When analyzing the prevalence and factors associated with constipation in adult women living in a municipality in the interior of Northeastern Brazil, a prevalence of $35.4 \%$ was found to be associated with clinical factors, such as the presence of hemorrhoids, pain and burning during bowel movement, and sexual dysfunction. Other investigated variables such as age, physical inactivity, education and obstetric factors were not associated with this condition.

In Brazil, Schmidt and Santos ${ }^{(17)}$ found an estimated IC prevalence of $16 \%$ in their study in the city of Londrina, and women were the most affected with frequencies which varied by self-report and by the Rome III Criteria of between $21 \%$ to $24 \%$ compared with men whose prevalence ranged from $4 \%$ to $6 \%$. In another population-based study which investigated IC prevalence and associated 
TABLE 1. Bivariate analysis of study population characterization, lifestyle, clinical aspects and obstetric history of adult women. Santa Cruz, Rio Grande do Norte, Brazil - 2016.

\begin{tabular}{|c|c|c|c|c|c|}
\hline & \multicolumn{4}{|c|}{ Constipação - $35.4 \%$} & \multirow{3}{*}{$\begin{array}{c}P \\
\text { value }\end{array}$} \\
\hline & \multicolumn{2}{|c|}{ Yes $(n=69)$} & \multicolumn{2}{|c|}{ No $(n=126)$} & \\
\hline & $\mathrm{n}$ & $\%$ & $\mathrm{n}$ & $\%$ & \\
\hline \multicolumn{6}{|l|}{ Age } \\
\hline Young adult (19 to 24 years old) & 15 & 21.7 & 25 & 19.8 & 0.94 \\
\hline Adult ( 25 to 39 years old) & 33 & 47.8 & 63 & 50.0 & \\
\hline Middle aged (40 until 49 years old) & 21 & 30.5 & 38 & 30.2 & \\
\hline \multicolumn{6}{|l|}{ Ethnicity } \\
\hline White & 20 & 29.0 & 38 & 30.2 & 0.86 \\
\hline Others & 49 & 71.0 & 88 & 69.8 & \\
\hline \multicolumn{6}{|l|}{ Education } \\
\hline Until elementary school & 32 & 46.4 & 61 & 48.4 & 0.79 \\
\hline High school or higher & 37 & 53.6 & 65 & 51.6 & \\
\hline \multicolumn{6}{|l|}{ Income } \\
\hline Up to 1 minimum monthly salary & 57 & 82.6 & 98 & 77.8 & 0.42 \\
\hline$>1$ minimum monthly salary & 12 & 17.4 & 28 & 22.2 & \\
\hline \multicolumn{6}{|l|}{ Marital status } \\
\hline Without partner & 27 & 39.1 & 64 & 50.8 & 0.12 \\
\hline With partner & 42 & 60.9 & 62 & 49.2 & \\
\hline \multicolumn{6}{|l|}{ Physical inactivity } \\
\hline Yes & 10 & 14.5 & 29 & 23.0 & 0.16 \\
\hline No & 59 & 85.5 & 97 & 77.0 & \\
\hline \multicolumn{6}{|l|}{ Self-rated of health } \\
\hline Good & 48 & 69.6 & 97 & 77.0 & 0.26 \\
\hline Poor & 21 & 30.4 & 29 & 23.0 & \\
\hline \multicolumn{6}{|l|}{ Hemorrhoids } \\
\hline Yes & 10 & 14.5 & 4 & 3.2 & $0.03 *$ \\
\hline No & 59 & 85.5 & 122 & 96.8 & \\
\hline \multicolumn{6}{|l|}{ Pain during evacuation } \\
\hline Yes & 32 & 46.4 & 6 & 4.8 & $0.001 *$ \\
\hline No & 37 & 53.6 & 120 & 95.2 & \\
\hline \multicolumn{6}{|l|}{ Pruritus ani } \\
\hline Yes & 4 & 5.8 & 1 & 0.8 & $0.03 *$ \\
\hline No & 65 & 94.2 & 125 & 99.2 & \\
\hline \multicolumn{6}{|l|}{ Presence of blood in the stool } \\
\hline Yes & 16 & 23.2 & 2 & 1.6 & $0.001 *$ \\
\hline No & 53 & 76.8 & 124 & 98.4 & \\
\hline \multicolumn{6}{|l|}{ Burning sensation during evacuation } \\
\hline Yes & 18 & 26.1 & 0 & 0 & $0.001 *$ \\
\hline No & 51 & 73.9 & 126 & 100.0 & \\
\hline \multicolumn{6}{|l|}{ Cesarean } \\
\hline Yes & 26 & 37.7 & 52 & 41.3 & 0.62 \\
\hline No & 43 & 62.3 & 74 & 58.7 & \\
\hline \multicolumn{6}{|l|}{ Vaginal delivery } \\
\hline Yes & 36 & 52.2 & 55 & 46.7 & 0.25 \\
\hline No & 33 & 47.8 & 71 & 56.3 & \\
\hline Episiotomy & & & & & \\
\hline Yes & 17 & 24.6 & 39 & 31.0 & 0.35 \\
\hline No & 52 & 75.4 & 87 & 69.0 & \\
\hline Dysmenorrhea & & & & & \\
\hline Yes & 45 & 65.2 & 64 & 50.8 & $0.05 *$ \\
\hline No & 24 & 34.8 & 62 & 49.2 & \\
\hline Sexual disfunction & & & & & \\
\hline Yes & 32 & 46.4 & 38 & 30.2 & $0.02 *$ \\
\hline No & 37 & 53.6 & 88 & 69.8 & \\
\hline
\end{tabular}

$* P$-value $<0.05 . P$-value calculate by chi-square test.
TABLE 2. Multivariate analysis of clinical and obstetric aspects of adult women. Santa Cruz, Rio Grande do Norte, Brazil - 2016.

\begin{tabular}{|c|c|c|c|c|c|c|}
\hline & $\begin{array}{c}\text { PR } \\
\text { crude }\end{array}$ & $95 \% \mathrm{CI}$ & $P$ value & $\begin{array}{c}\text { PR } \\
\text { adjusted }\end{array}$ & $95 \% \mathrm{CI}$ & $P$ value \\
\hline \multicolumn{7}{|c|}{ Pain during evacuation } \\
\hline Yes & 3.95 & $2.76-5.65$ & $0.001 *$ & 2.76 & $1.90-4.06$ & $0.001 *$ \\
\hline No & 1.00 & & & 1 & & \\
\hline \multicolumn{7}{|c|}{ Burning sensation during evacuation } \\
\hline Yes & 3.60 & $2.75-4.72$ & $0.001 *$ & 1.64 & $1.17-2.31$ & $0.01 *$ \\
\hline No & 1.00 & & & 1 & & \\
\hline \multicolumn{7}{|c|}{ Hemorrhoids } \\
\hline Yes & 2.22 & $1.48-3.35$ & $0.001 *$ & 1.93 & $1.16-3.20$ & $0.01 *$ \\
\hline No & 1.00 & & & 1 & & \\
\hline \multicolumn{7}{|c|}{ Sexual disfunction } \\
\hline Yes & 1.52 & $1.04-2.21$ & $0.03 *$ & 1.45 & $1.04-2.04$ & $0.03 *$ \\
\hline No & 1 & & & 1 & & \\
\hline \multicolumn{7}{|c|}{ Dysmenorrhea } \\
\hline Yes & 1.16 & $1.02-1.32$ & $0.03 *$ & 1.32 & $0.91-1.91$ & 0.14 \\
\hline No & 1 & & & 1 & & \\
\hline \multicolumn{7}{|c|}{ Presence of blood in the stool } \\
\hline Yes & 1.73 & $0.82-3.63$ & 0.15 & & & \\
\hline No & 1 & & & & & \\
\hline \multicolumn{7}{|c|}{ Pruritus ani } \\
\hline Yes & 1.91 & $0.84-4.35$ & 0.12 & & & \\
\hline No & 1 & & & & & \\
\hline
\end{tabular}

factors in adults in the city of Pelotas-RS, the authors identified a prevalence of $25.6 \%$ of constipation through self-report and $26.9 \%$ through using the Rome Criteria III. The prevalence of IC was 2.5 times also more frequent in women $(36.9 \%)$ than in men $(14 \%)$ in this study ${ }^{(10)}$. However, there are no official statistics in Brazil, nor studies in other regions of the country. The National Health Policy (PNS), for example, does not raise questions about this theme ${ }^{(18)}$.

Biomechanical aspects involved in bowel movement may contribute to a higher prevalence of constipation in women, such as pelvic floor muscle and nerve injury which may occur during vaginal delivery, for example ${ }^{(19)}$. Alterations in the pelvic floor muscles predispose to problems such as urinary incontinence, sexual dysfunction and constipation. Impaired pelvic floor function is believed to be one of the factors which may explain the association between constipation and sexual dysfunction, which may explain the outcome of this study ${ }^{(20)}$. There are few studies in the literature evaluating the impacts of constipation on sexual function. However, a recent review ${ }^{(21)}$ shows that early evidence suggests that IC is associated with difficulties in female sexual function.

In the present study, $79.5 \%$ of participants have a monthly family income of up to one minimum monthly salary. Although income was not a variable associated with IC prevalence, there is previous evidence in the literature of an increased constipation prevalence associated with low socioeconomic status ${ }^{(22,23)}$. This is perhaps explained by the influence of social standards in favoring higher risk behavior such as poor diet and physical inactivity in individuals from disadvantaged classes $^{(24)}$.

The association of hemorrhoids and pain and burning during evacuation identified in this study are explained by the pathophysiology of intestinal constipation itself ${ }^{(25)}$. Functional defeca- 
tion disorders are associated with many factors, including rectal hypersensitivity, altered rectal reflex activity, increased rectal duct capacity, and rectal motor dysfunction ${ }^{(3)}$, and are associated with a fear of defecating pain due to the presence of bulky or hard stools, hemorrhoids and anal fissure ${ }^{(25)}$.

Riss et al. ${ }^{(26)}$ claim that little is known about the connection between hemorrhoids and anorectal function. The authors describe that complaints such as pain, effort and need for evacuation stimulation is common in constipated patients (laxatives, finger maneuvers or enemas) and expressed significant correlation with the presence of hemorrhoids, and this is because there are varicose veins present in the rectum which can be aggravated by exertion during bowel movements. In their study, these authors observed that individuals with a higher degree of hemorrhoids showed an increase in constipation symptoms.

On the other hand, the presence of pain and burning during bowel movements is mainly related to stool consistency, which leads to excessive, prolonged and sometimes unsatisfactory defecatory effort, causing the individual to perform finger or manual maneuvers to be able to expel the stool ${ }^{(1)}$.

Del' $\operatorname{Arco}^{(27)}$ found in their study that gastrointestinal diseases, including constipation, negatively impact different elements of quality of life in Brazilian women, such as mood, concentration and sexuality, so studying the prevalence and correct management of this condition is important. Thus, this study seeks to contribute by identifying factors which are related to IC and to support planning actions aimed at patients suffering from constipation through these findings, thus improving the care provided by health professionals.

Physical inactivity in this study was not associated with the IC prevalence, and this may have happened because only physical activity was evaluated, not physical exercise. However, physical activity and proper nutrition appear as important actions to regulate gastrointestinal motility, as a high-fiber diet can increase stool weight, resulting in a shorter colon transit time, while a low-fiber diet leads to constipation ${ }^{(27)}$, while physical activity can increase propulsion movements in the large intestine ${ }^{(28)}$.

No association of constipation with age was observed. This may be due to the fact that the studied sample was only composed of adult women. The literature shows a difference between the group of young and older individuals, but this population was not investigated in this study ${ }^{(29)}$.

As limitations of this work, we highlight the cross-sectional design which limits interpreting the data to associations, susceptible to reverse causality, and also precludes a better understanding of the phenomenon due to the impossibility of establishing causality ${ }^{(30)}$. Another limitation may be related to clinical aspects relevant to understanding IC such as anthropometric data, body composition, and body water percentage, but not included in this study due to the logistical difficulty to measure variables in epidemiological studies. In addition, inaccurate questionnaires such as IPAQ were used. As the study was developed from a population in a small town, other studies with methodological designs more representative of the Brazilian population are encouraged.

\section{CONCLUSION}

There are high prevalence of constipation between adult and middle age women. Clinical factors like hemorrhoids, pain and burning sensation during evacuation, and sexual dysfunctions are associated with constipation. Sociodemographic factors and life habits as physical activity did not associated with this condition.

\section{Authors' contribution}

AAG Dantas: conceptualization, data curation, formal analysis, writing-original draft and review \& editing; IR Barbosa: data analysis and writing-original draft; SS Castro: writing-original draft and review \& editing; SMA Camara: writing-original draft and review \& editing; DS Dantas: conceptualization, supervision, data curation, formal analysis, writing-original draft and review \& editing.

\section{Orcid}

Amanda Almeida Gomes Dantas: 0000-0002-7621-086X.

Isabelle Ribeiro Barbosa: 0000-0002-1385-2849.

Shamyr Sulyvan de Castro: 0000-0002-2661-7899.

Caroline Wanderley Souto Ferreira: 0000-0003-2736-5918.

Saionara Maria Aires da Camara: 0000-0002-3054-7213.

Diego de Sousa Dantas: 0000-0002-1966-3352.

Dantas AAG, Barbosa IR, Castro SS, Ferreira CWS, Camara SMA, Dantas DS. Prevalência e fatores associados à constipação em mulheres na pré-menopausa: um estudo de base comunitária. Arq Gastroenterol. 2020;57(2):188-92.

RESUMO - Contexto - A constipação intestinal é caracterizada por problemas relacionados à evacuação, e apresenta alta prevalência no gênero feminino.

Essa condição tem demonstrado efeitos negativos no desenvolvimento das atividades diárias, causando prejuízos no bem-estar físico e emocional dos indivíduos que são diagnosticados com ela. Estudos que investiguem quais prejuízos à saúde a constipação intestinal pode ocasionar são escassos na literatura. Objetivo - Este estudo teve como objetivo verificar a prevalência e os fatores associados à constipação intestinal em mulheres na pré-menopausa residentes no nordeste do Brasil. Métodos - Estudo transversal realizado no Nordeste do Brasil. Participaram 195 mulheres adultas e de meia idade. Condições sociais, hábitos e estilo de vida, aspectos clínicos e história obstétrica foram investigados. A constipação foi diagnosticada através dos Critérios de Roma III. A análise multivariada foi conduzida através da Regressão de Poisson com variância robusta, para analisar a relação entre constipação intestinal e variáveis independentes. Considerou-se o nível de significância estatística de $P \leq 0,05$. Resultados - A maioria das mulheres estava na faixa etária de 25 a 39 anos $(49,2 \%)$ e possuía renda de até um salário mínimo (79,5\%). A prevalência da constipação intestinal foi de 35,4\%. No modelo final da regressão multivariada, os aspectos clínicos hemorroidas $(P<0,01)$, dor $(P<0,001)$ e ardor $(P<0,01)$ ao evacuar e disfunção sexual $(P<0,03)$ permaneceram associados à constipação. Conclusão - O presente estudo encontrou uma prevalência significativa de constipação entre mulheres na pré-menopausa e fatores clínicos como hemorroidas, dor e ardor na evacuação, e disfunção sexual se associaram a constipação intestinal.

DESCRITORES - Constipação intestinal. Saúde da mulher. Pré-Menopausa. Epidemiologia. 


\section{REFERENCES}

1. WGO. World Gastroenterology Organisation Practice Guidelines. Constipação: uma perspectiva mundial. Novembro, 2010.

2. Sun SX, Dibonaventura M, Purayidathil FW, Wagner JS, Dabbous O, Mody R Impact of chronic constipation on health-related quality of life, work productivity and health resource use: an analysis of the National Health and Welfare Survey. Dig Dis Sci. 2011;56:2688-95.

3. Sanchez MI, Bercik P. Epidemiology and burden of chronic constipation. Can J Gastroenterol. 2011;25 (Suppl B):11B-15B.

4. Forootan M, Bagher N, Darvishi M. Chronic constipation A review of literature Medicine (Baltimore). 2018;97:e10631.

5. Iraji N, Keshteli AH, S Sadeghpour, Daneshpajouhnejad P, Fazel M, Adibi P. Constipation in Iran: SEPAHAN Systematic Review No 5. Int J Prev Med. 2012;3(Suppl 1):S34-41.

6. Sommers T, Mitsuhashi S, Singh P, Hirsch W, Katon J, Ballou S, et al. Prevalence of Chronic Constipation and Chronic Diarrhea in Diabetic Individuals in the United States. Am J Gastroenterol. 2019;114:135-42.

7. Ji-Eun Oh, Yong-Woon Kim, Parque So-Young, Jong-Yeon Kim. Estrogen, instead of progesterone, causes constipation in female and male mice. Coreano J Physiol Pharmacol. 2013;17:423-6.

8. Belsey J, Greenfield S, Candy D, Geraint M. Systematic review: Impact of constipation on quality of life in adults and children. Aliment Pharmacol Ther 2010;31:938-49.

9. Instituto Brasileiro de Geografia e Estatística. Cidades@. [Internet] [Access 2014 November] Available from: http://www.cidades.ibge.gov.br/xtras/perfil. php?lang=\&codmun $=2411$.

10. Collete VL, Araújo CL, Madruga SW. Prevalência e fatores associados à constipação intestinal: um estudo de base populacional em Pelotas, Rio Grande do Sul, Brasil. Cad Saúde Pública. 2010;26:1391-402. Doi: 10.1590/S0102311X2010000700018

11. Longstreth GF, Thompson WG, Chey WD, Houghton LA, Mearin F, Spiller RC. Functional bowel disorders. Gastroenterology. 2006;130:1480-91.

12. IPAQ Research Committee. Guidelines for Data Processing and Analysis of the International Physical Activity Questionnaire (IPAQ). International Physical Activity Questionnaire (IPAQ). 2005;1-15.

13. Pardini R, Matsudo SM, Araújo, T, Matsudo V, Andrade E, Braggion G. Validação do questionário internacional de nível de atividade física (IPAQ versão 6): estudo piloto em adultos jovens brasileiros. Rev Bras Ciên e Mov. 2001;9:45-51.

14. Dawes J. Do data characteristics change according to the number of scale point used? An experiment using 5-point, 7-point and 10-point scales. International Journal of Market Research. 2008;50:61-77.

15. Abdo CHN. Quociente sexual feminino: um questionário brasileiro para avaliar a atividade sexual da mulher. Diagn Tratamento. 2009;14:89-1.
16. Abdo CHN. Elaboração e validação do quociente sexual - versão feminina, uma escala para avaliar a função sexual da mulher. RBM Rev Bras Med. 2006;63:477-82.

17. Schmidt FMQ, Santos VLCG, Domansky RC, Barros E, Bandeira MA, Tenório MAM, Jorge JMN. Prevalence of self-reported intestinal constipation in adults of the general population. Rev Esc Enferm USP. 2015;49:440-9.

18. Instituto Brasileiro de Geografia e Estatística. Pesquisa Nacional de Saúde. [Internet] 2013. [Access 2019 January] Available from: <http://www.ibge.gov.br/home/ presidencia/noticias/imprensa/ppts/0000001410010811201301571283436.pdf>.

19. Fradet M, Deparis C, Gachon J, Sichitiu B, Pierre J, Frite F, Desseauve D. Lesions and symptoms of the obstetric anal sphincter after subsequent deliveries: a study of 60 patients. Eur J Obstet Gynecol Reprod Biol. 2018;222:40-6.

20. Goa G, Ding S, Ding Y, Jin X, Chen Q, Zhou H, et al. Distribution of the symptoms of patients with female pelvic floor dysfunction with constipation as the main complaint. Zhonghua Wei Chang Wai Ke Za Zhi. 2018;21:798-802.

21. Thomas GP, Maeda Y, Vaizey CJ. A review of the effect of faecal incontinence and constipation on sexual function. Int J Colorectal Dis. 2019;34:387.

22. Bytzer P, Howell S, Leemon M, Young LJ, Jones MP, Talley NJ. Low socioeconomic class is a risk factor for upper and lower gastrointestinal symptoms: a population based study in 15,000 Australian adults. Gut. 2001;49:66-72.

23. Shi H, Yao L, Zhou M. Correlation Analysis between Chronic Functional Constipation and Syndrome Caused by Northwest Dryness-evil. Xinjiang Journal of Traditional Chinese Medicine. 2010;(2):5-7. Available from: http://caod. oriprobe.com/articles/23453121/Correlation_Analysis_between_Chronic_Functional_Constipation_and_Syndr.htm

24. Stewart WF, Liberman JN, Sandler RS, Woods MS, Stemhagen A, Chee E, et al. Epidemiology of constipation (EPOC) study in the United States: Relation of clinical subtypes to sociodemographic characteristics. Am J Gastroenterol. 1999; 12:3530-40.

25. Alves JG. Constipação Intestinal. JBM. 2013;101:31-7.

26. Riss S, Weiser FA, Schwameis K, Mittlböck M, Stift A. Haemorrhoids, constipation and faecal incontinence: is there any relationship? Colorectal Dis. 2011;13:227-33.

27. Del'arco A, Magalhaes P, Quilici FA. SIM Brasil study women's gastrointestinal health: gastrointestinal symptoms and impact on the Brazilian women quality of life. Arq Gastroenterol. 2017;54:115-22.

28. Moezi P, Salehi A, Molavi H, Hossein Poustchi H, Gandomkar A, Imanieh MH, Malekzadeh R. Prevalence of chronic constipation and its associated factors in the pars cohort study: a study of 9,000 adults in Southern Iran. Middle East J Dig Dis. 2018;10:75-83.

29. Walter S, Hallbook O, Gotthard R, M Bergmark, Sjodahl R. A population-based study of bowel habits in a Swedish community: prevalence of fecal incontinence and constipation. Scand J Gastroenterol. 2002;37:911-26.

30. Fletcher RH, Fletcher SW. Epidemiologia Clínica: elementos essenciais. $4^{\circ}$ ed. Porto Alegre: Artmed; 2006. 